\title{
Financial Regulation And Supervision: Theory And Practice In South Africa
}

Erika Botha, University of South Africa, South Africa

Daniel Makina, University of South Africa, South Africa

\begin{abstract}
This paper discusses the theory of financial regulation and practices in countries and South Africa in particular. One of the causes of the global financial crisis (2007-2009) often cited is inadequate or improper regulation and supervision of the financial sector. The global financial crisis revealed inadequacies of extant regulatory systems which arguably had not kept pace with financial innovation. Consequently, all major economies are reforming their regulatory systems in the aftermath. In the UK the Financial Services Authority (FSA) has devised a set of banking regulation while the USA enacted the Dodd-Frank Act to revamp the regulation of financial services. Historically, financial regulation and supervision has been premised on the silo (institutional) approach whereby institutions are regulated according to functional lines. However, in the past two decades many countries in advanced economies adopted a consolidated approach in response to the emergence of financial conglomerates whose regulation could not be adequately handled by the traditional silo approach. South Africa, a middle-income developing country, has had a regulatory and supervisory system that has been driven by the market and international trends. Having started as a institutional approach, it metamorphosed into a functional approach in the late 1980s. Since the 1990s the South African regulatory and supervisory system has had at its heart the central bank regulating the banking sector and a multisector regulatory approach for other non-banking financial services. Though the financial sector was largely unscathed by the global financial crisis, South Africa has also moved to reform its regulatory system to embrace the "twin peak" model in line with trends in related countries.
\end{abstract}

Keywords: Financial Regulation; Supervision; Silo Model; Unified Model; Hybrid Model; Twin Peak Model; South Africa

\section{INTRODUCTION AND BACKGROUND}

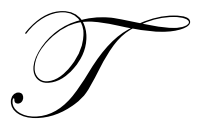

he terms regulation and supervision denote respectively the establishment of rules relating to a particular industry and the monitoring and enforcement thereof. Broadly, the objectives of financial regulation cited in the literature are four-fold, viz.: (1) to protect consumers or investors; (2) to ensure the solvency and financial soundness of financial institutions; (3) to promote fairness, efficiency and transparency in the securities markets; and (4) to promote a stable financial system. According to Goodhart et al. (1998) the important role played by the financial system dictates that financial institutions need to be regulated for three main reasons, viz: consumer protection, stability of the financial system, and maximizing efficiency.

While the global financial crisis of 2007-2009 has heightened the debate on financial regulation, the debate had already been ongoing well before the onset of crisis. Traditionally, a silo or institutional approach to financial regulation has been applied. This is a system whereby the three broad financial sectors -banking, insurance and securities sectors- have been regulated separately. The financial sector has however continuously evolved to challenge the traditional approach. Globalization has brought about financial market integration. Financial markets have grown more integrated and complex increasing the risk of financial contagion during crises. The nature of financial intermediation has changed and we have witnessed the rise of hedge funds and private equity funds that until recently have operated informally and outside the traditional regulatory framework. New financial instruments and exotic derivatives have emerged as a result of financial innovation and engineering. For instance, there is proliferation of over-the-counter financial instruments such as collateralized debt obligations (CDOs) whose risks 
regulators have not yet fully comprehended. Competition in the financial sector has resulted in dominance by a small number of huge institutions and has created financial conglomerates which in turn have resulted in regulatory arbitrage (Davies and Green, 2008).

Goodhart et al (1998: 143) observe that the emergence of financial conglomerates has posed a challenge to the traditional demarcations between regulatory agencies as espoused by the silo approach. Policy makers have pondered on how best to regulate innovation and financial conglomerates. When the Labour Government came into power in the UK in May 1997, they advocated for centralization of financial regulation and this led to consolidation of regulatory and supervisory powers in the Financial Services Authority (FSA). In contrast US bank regulation is highly fragmented and allowed for regulatory competition. Masciandaro and Quintyn (2009) observe that the shortcomings of the US regulatory structure were evident before the global financial crisis and that the crisis only exposed the failure of the argument for regulatory competition which was the cornerstone for the rationale of the US system.

While most countries have moved from the silo based approach to financial regulation, there is no agreement on the best regulatory structure a country should adopt. So far, the choices have ranged from (1) a silos (institutional) model, (2) unified (integrated) model, (3) peaks model and (4) functional (hybrid) model depending on the country's development of the financial system and circumstances. Each of these models has some weaknesses and strengths. It is in this context that this paper examines the strengths and weaknesses of the South African regulatory system, comparing it with international practice and identifying reform pathways.

The rest of the paper is structured as follows. Section 2 discusses the theory of financial regulation. Section 3 discusses international financial regulation and supervision practices. Section 4 discusses the South African regulatory and supervisory system and section 6 concludes.

\section{THE THEORY AND RATIONALE FOR FINANCIAL REGULATION}

The economic theory of regulation was first published by Stigler in 1971. The Stigler (1971) theory's crucial element was the integration of the analysis of political behaviour with economic analysis. The evolution of the theory has centred on two basic schools of thought, namely, positive theories of regulation and normative theories of regulation (see for instance, Joskow and Noll, 1981).

As elucidated in the Body of Knowledge on Infrastructure Regulation ${ }^{1}$, positive theories of regulation which include theories of market power, interest group theories and theories of government opportunism attempt to explain the need for regulation. Theories of market power and interest group theories endeavour to explain stakeholders' interests in regulation while theories of government opportunism explain why restrictions on government discretion need to be regulated in order to facilitate efficient provision of services. According to the Body of Knowledge on Infrastructure Regulation, these theories explain that regulation happens because of either of the following scenarios:

- Where the government would like to minimize information asymmetries and to align an operator's interest with its interest;

- Where consumers would like protection from monopoly power where competition does not exist or is not effective;

- Where market operators would like protection from rivals; and

- Where operators themselves would like protection from government opportunism.

On the other hand, normative theories of regulation postulate that regulators should encourage competition where possible. It is argued that through information gathering, regulators should assist in reducing the costs of information asymmetries and provide operators with performance improving incentives.

The basic economic rationale for financial regulation is that financial market activity generates externalities that are not easily addressed by private agents. The problem is that externalities generate social cost in the event of

${ }^{1}$ See http://www.regulationbodyofknowledge.org/ accessed on 10 March 2011. 
failure, especially when this cost is greater than the private cost and the social cost does not form part of the decision making function of the institutions, especially banks. This behaviour can cause financial institutions to take more risks and spend more money as opposed to the social cost being incorporated into the overall pricing of the institution. This systematic issue of social cost was traditionally the primary reason of the central function of regulation of the banking industry (Falkena et al., 2001:12). Though there is always a problem in measuring externalities, in principle regulatory intervention can only be justified where benefits exceed the costs imposed, but costs are usually easier to quantify than the benefits.

Two principal strands to the rationale for regulating financial markets, viz: to mitigate the problem of systemic risk and to regulate conduct of business in the financial market. Falkena, et al (2001:2) further assert that the main objective of financial regulation is to protect the consumer and achieve a high degree of economic efficiency in the market. The protection of the consumer arises from either the institution failing the client who holds funds within it or where the institution's conduct of business is unsatisfactory.

When financial systems are left to themselves, they have been found to be prone to spells of instability and contagion. The World Bank (2001) reports 112 systemic banking crises in 93 countries between the late 1970s and the end of the twentieth century. Eichengreen and Bordo (2002) have argued that crises are more prevalent today than they were in the pre-1914 era of financial globalization indicating that the incidence of financial crisis has tended to rise as financial markets have become more liberalised and globalized. Falkena et al. (2001:11) observe that the three main elements of a financial or banking crisis are: (1) the incentive structures are not motivational; (2) the management and control systems within the bank are weak; (3) regulations, monitoring and supervision are of poor quality.

Prudential supervision of banks stems from the basis that banks through their role in maturity transformation and the provision of liquidity has a special position in the financial system. Being at the centre of the payments network, the failure of one bank can bring about a domino effect on others and the resulting potential externalities cannot easily be internalized. Banks do not necessarily take account of the potential external cost to the economy of their failure and hence they tend to take greater risks than they would do if there was a market for this risk. Thus the goal of supervision is to prevent potentially excessive risk taking by requiring banks to hold larger reserves than they might otherwise do and to conduct their business with more careful attention to risk (Davies and Green, 2008). These arguments tend to be a justification for a lender of last resort role played by central banks. However, noting that the existence of a lender of last resort function has a cost, Davies and Green (2008) further argue that there should be a clear distinction between providing liquidity support to a fundamentally sound bank and providing solvency support but observe that the two are confused in practice. Continuous supervision in the form of monitoring the capital reserve position and risk management arrangements of banks is meant to reduce the expected cost of the central bank as the lender of last resort.

Regulating conduct of business is justified on the basis that there are information asymmetries in the market which a regulatory system can help to reduce. Due to asymmetric information in the financial markets, shareholders have less information about the economic conditions of institutions in which they want to invest giving rise to adverse selection of investments and moral hazard behaviour by financial institutions (Mishkin, 2004). Governments address these issues of adverse selection and moral hazard through regulation that, among other things, requires financial institutions to disclose certain information to the public.

\section{INTERNATIONAL PRACTICE AND EXPERIENCE}

Financial regulation regimes in many countries are generally fragmented. A banking survey conducted by the Economist Intelligence Unit (2006) showed that over one-third of banks report to 10 or more regulators and over $75 \%$ of all banks report to four or more regulators. It also showed that only $3 \%$ of banks reported to a single regulator. A global bank was shown to have more than 350 regulatory exams a year, an indication of the increasing complexity of financial markets that is making compliance very burdensome and costly for multinational banks.

In practice, there are essentially four approaches to financial regulation and supervision: the silos (institutional) model, the integrated (unified) model, the peaks (horizontal) model and the (functional) hybrid model. 
The silos model or institutional model is the traditional approach that appropriates financial regulation according to main functional lines -banking, insurance and securities industry. In other words, it follows the boundaries of the financial system in different sectors, and where every sector is supervised by a different agency. The central bank is usually assigned the responsibility for prudential and systemic regulation of the banking sector. The regulation of the conduct of business in the sector is partially done through self-regulation whereby a council or a committee selected by the regulators and industry players is assigned.

Typically, financial institutions have also tended to address compliance with a silos approach. Compliance and risk activities are often carried out by different departments using different information sets. This has resulted in financial institutions managing governance, risk and compliance in an uncoordinated manner despite risks having become interdependent and the need for controls to be shared across the entire organization. Such parallel compliance and risk activities have increased the cost of compliance (Economist Intelligence Unit, 2006).

The silos model has a number of shortcomings, especially with regard to regulating financial conglomerates which are now a common feature of financial institutions. Typically, the model introduces inconsistency when a financial conglomerate or group operates in the three main industries of the sector, viz.: banking, insurance and securities sectors. Such a financial group would then be required to be regulated by three different regulators. This provides space for regulatory arbitrage whereby tighter regulation in one sector is compensated by moving operations to sectors where regulation is not too tight. A financial group would for example reduce the required aggregate capital in the banking sector by spreading risks to the securities and/or insurance sectors where capital requirements are generally lower. The second problem is that each sector by virtue of having a different regulator may be viewed as a separate entity from the holding company. As a result, the risk assumed by a financial group could end up being larger or smaller than the sum of the risk of its subsidiaries depending on whether all are regulated or not. However, the less regulated subsidiaries of a financial group could pose instability to the entire group.

In fact the growing importance of financial groups was a factor to the trend to unify regulatory and supervisory structures in Europe in the late 1980s. The unified or integrated model is where the financial regulation and supervision covering banking, securities and insurance markets is completely integrated. In the integrated model there is a single universal regulator that conducts both safety and soundness oversight and conduct of business regulation for all the sectors of financial services. Its stated advantage is its "unified focus on regulation and supervision without confusion or conflict over jurisdictional lines" inherent under either the silo approach or the functional approach (G30 report, 2008: 14). However, its shortcoming is that it could create "the risk of a single point of regulatory failure" and presents challenges in coordinating regulators.

In the aftermath of domestic financial crises, Scandinavian countries consolidated their regulatory agencies -Norway in 1986, Iceland and Denmark in 1988 and Sweden in 1991. According to Taylor and Fleming (1999), the creation of unified regulatory agencies was market-driven and was intended to make regulation effective. In June 1998 the UK decided to assign the task of regulating and supervising the entire financial system to a single authority other than the central bank. The responsibility for banking supervision was transferred from the Bank of England to a new body, the Financial Services Authority (FSA). On the backdrop of the UK move to unified system, more countries followed suit as cited by Masciandaro and Quintyn (2009). Austria [2002], Belgium [2004] and Germany [2002] also assigned the role of supervising the entire financial system to a single authority other than the central bank. In contrast, supervisory responsibilities were concentrated in the central bank in Ireland [2003] and the Czech and Slovak Republic [2006]. New entrants to the EU that have embraced a single authority are Estonia [1999], Latvia [1998], Malta [2002], Hungary [2000] and Poland [2006], and outside Europe the unified model has been established in Kazakhstan, Korea, Japan and Nicaragua (Masciandaro and Quintyn, 2009).

The twin peaks (horizontal) model is premised on the differences among public goals of regulation and assigns a different regulatory authority to every goal (Taylor, 1995). It is defined by the G30 report (2008) as a form of regulation by objective, one in which there is a separation of regulatory functions between two regulators whereby one performs the safety and soundness supervision function while the other focuses on conduct of business regulation. It is an approach designed to incorporate the efficiencies and benefits from the intergraded approach but also to make provision for conflict that may exist between consumer protection and transparency and the safety and 
soundness of regulation objectives. Australia and the Netherlands are some of the few countries that make use of the twin peak approach and its merits have been debated by countries such as France, Italy, Spain and the United States (G30 report, 2008).

The functional or hybrid model as implemented by Italy and France is not based on the legal status of a business but rather on the type of business being performed by the entity to be regulated without regard to its legal status (G30 report, 2008). Each type of business may be assigned its own functional regulator. This model works well if coordination between the agencies can be maintained, but can pose a difficulty in determining the type of activity of the business to be subjected to regulation. The US financial system is best described purely hybrid in the sense that it has both functional and institutional aspects but with the added complexity of a number of state-level agencies and actors (G30 report, 2008). The 2007- 2009 global financial crisis exposed the weaknesses of the system and the US Treasury "Blueprint of a Modernized Financial Regulatory Structure" mooted in March 2008 advocated for a modified twin peaks approach as a long-term goal. However, in the US historical precedent, politics, and culture play an important role in the design of the regulatory structure as evidenced by the Dodd-Frank Wall Street and Consumer Protection Act enacted in July 2010 that revamped the regulation of financial services. The main element of the Act was the creation of the Financial Stability Oversight Council (FSOC) to serve as an earlywarning system to identify risks in forms and market activities, to enhance oversight of the financial system as a whole and to harmonize prudential standards across agencies.

According to Masciandaro and Quintyn (2009), before the widespread reforms of the 2000s the distribution of the models of financial regulation and supervision in a sample of 102 advanced countries comprised: $35 \%$ of sampled countries followed the silos (institutional) model; 24\% followed the unified (integrated) model; $2 \%$ followed the twin peaks model (notably Australia and the Netherlands) and 39\% followed the hybrid (functional) model, notably in the US, France and Italy where the structure of the regulation and supervision can be explained from history or the political economy. Following the reforms implemented in the period $1988-2008,30 \%$ of the sample had adopted the unified model, 33\% the silos model, 33\% the hybrid model and $4 \%$ the twin peaks model. Some systems may not neatly follow this delineation but they still have elements of these four approaches. Table 1 shows an overview of the regulatory structures of selected countries worldwide.

Table 1: Regulatory Structures of Selected Countries

\begin{tabular}{|l|l|l|}
\hline \multicolumn{1}{|c|}{ Type of regulation } & \multicolumn{1}{|c|}{ Determining feature } & \multicolumn{1}{c|}{ Countries } \\
\hline Silo (institutional) approach & $\begin{array}{l}\text { The legal structure of the firm } \\
\text { determines the overseeing regulator }\end{array}$ & China, Hong Kong, Mexico \\
\hline Integrated (unified) approach & $\begin{array}{l}\text { Single regulator regulates all financial } \\
\text { sectors }\end{array}$ & $\begin{array}{l}\text { Canada, Germany, UK, Norway, } \\
\text { Iceland, Denmark, Sweden, Japan, } \\
\text { Qatar, Singapore }\end{array}$ \\
\hline Functional (hybrid) approach & $\begin{array}{l}\text { Supervisor oversight are determined by } \\
\text { the business of the firm }\end{array}$ & US, France, Italy. Brazil, Spain \\
\hline Twin peak approach & Regulation determined by objective. & Australia, Netherlands \\
\hline
\end{tabular}

Source: G30 Report (2008)

\section{THE SOUTH AFRICAN FINANCIAL REGULATORY SYSTEM}

The importance of the financial sector in the economy of South Africa is best understood by having reference to Table 2 below. Its share of GDP is $10.5 \%$ and financial sector assets are well over 200\% of GDP.

The financial services sector of South Africa is well-developed just like those in advanced economies such that regulatory issues are as equally important to warrant the attention of authorities both nationally and internationally. Internationally, South Africa is a member of G-20 countries and member of the Bank of International Settlements and has one seat on the Financial Stability Board that coordinates regulation at the international level. Its central bank is one of those that take active participation in Basel accords and compliance. The report by the International Monetary Fund (IMF) published in October 2008 observes that South Africa has a well diversified and refined 
financial system, which is supported by an "effective regulatory framework" as well as a developed financial and legal infrastructure.

Table 2: Snapshot of the Financial Services Sector of South Africa in 2010

\begin{tabular}{|l|c|}
\hline Component Description & Share of GDP \\
\hline Size (gross value added) & $10.5 \%$ \\
\hline Assets & $252 \%$ \\
Of which: & $127 \%$ \\
Banks & $60 \%$ \\
Long term insurers & $4 \%$ \\
Short term insurers & $62 \%$ \\
Pension funds (public and private) & Share of formal employment \\
\hline & $3.9 \%$ \\
\hline Employment & Share of corporate taxes \\
\hline
\end{tabular}

Source: South Africa National Treasury Policy Document (2011)

Prior the 1980s the South African regulatory structure sluggishly followed international trends whereby regulators rarely looked beyond the national borders. Capital requirements were based on simple ratios of capital to total assets. Off-balance sheet activities and derivatives were unregulated. Consolidated supervision was an unknown concept and the financial sector components -banks, insurance and the capital markets -were regarded as separate entities nationally and regulated separately. In other words, a silo or institutional approach was in place. Supervisory co-operation at an international level was still a mooted idea (Cooke, 1999). Owing to political isolation of South Africa during the 1980s due to the country's apartheid policies, co-operation with foreign regulators was almost non-existent. As a result the regulatory regime progressively became out of line with international best standards.

Between 1965 and 1980 the financial sector was heavily regulated. Deregulation only started to happen in the late 1980s following the commissioning of the De Kock Commission by the government in 1987. The De Kock Commission observed that institutional regulation had resulted in over-regulation in the banking sector making the sector inefficient and not competitive and recommended functional regulation (regulating specific activities) and risk-weighted equity rules. These recommendations were implemented through the Banking Act of 1990 that was based on first world criteria and principles (Basel rules) that focused on risk management and the regulatory structure became partially integrated with the central bank regulating the banking sector and a multi-sector regulatory approach for other non-banking financial services. In 1993 another government-sponsored commission, the Melamet Commission, recommended that South Africa adopt the unified regulatory approach to be in line with developments in European countries whose financial systems are similar. However, the regulatory system has remained functional and partially integrated to the present day. Figure 1 depicts a structure with two main regulatory authorities namely, the South African Reserve Bank (SARB) and the Financial Services Board (FSB). The deposittaking banking sector is regulated by the Banking Supervision Department of the SARB while non-banking financial institutions are regulated by the FSB independently from, but accountable to the National Treasury. Regulatory duties and powers for some industries are split horizontally. The Registrar of Companies which is in the Department of Trade and Industry and the Registrar of Medical Schemes in the Department of Health regulates medical schemes. Furthermore, the regulation of some functions is delegated to self-regulatory organizations or associations. For instance, the Johannesburg Securities Exchange (JSE) and the central securities depository operate, STRATE Ltd, as self-regulatory organizations. The credit industry is regulated by the National Credit Regulator whose objective is to promote fairness in accessing consumer credit, consumer protection and competitiveness in the credit industry (van Zyl et al., 2009).

Essentially, the South African regulatory and supervisory system has a number of disparate regulators coordinated through statutory bodies, advisory bodies and standing committees. It is best described as functional and split horizontally. It presently does not have an overarching coordinating authority. 
Figure 1: Present Regulatory Landscape in South Africa

Source: National Treasury Policy Document, 2011.
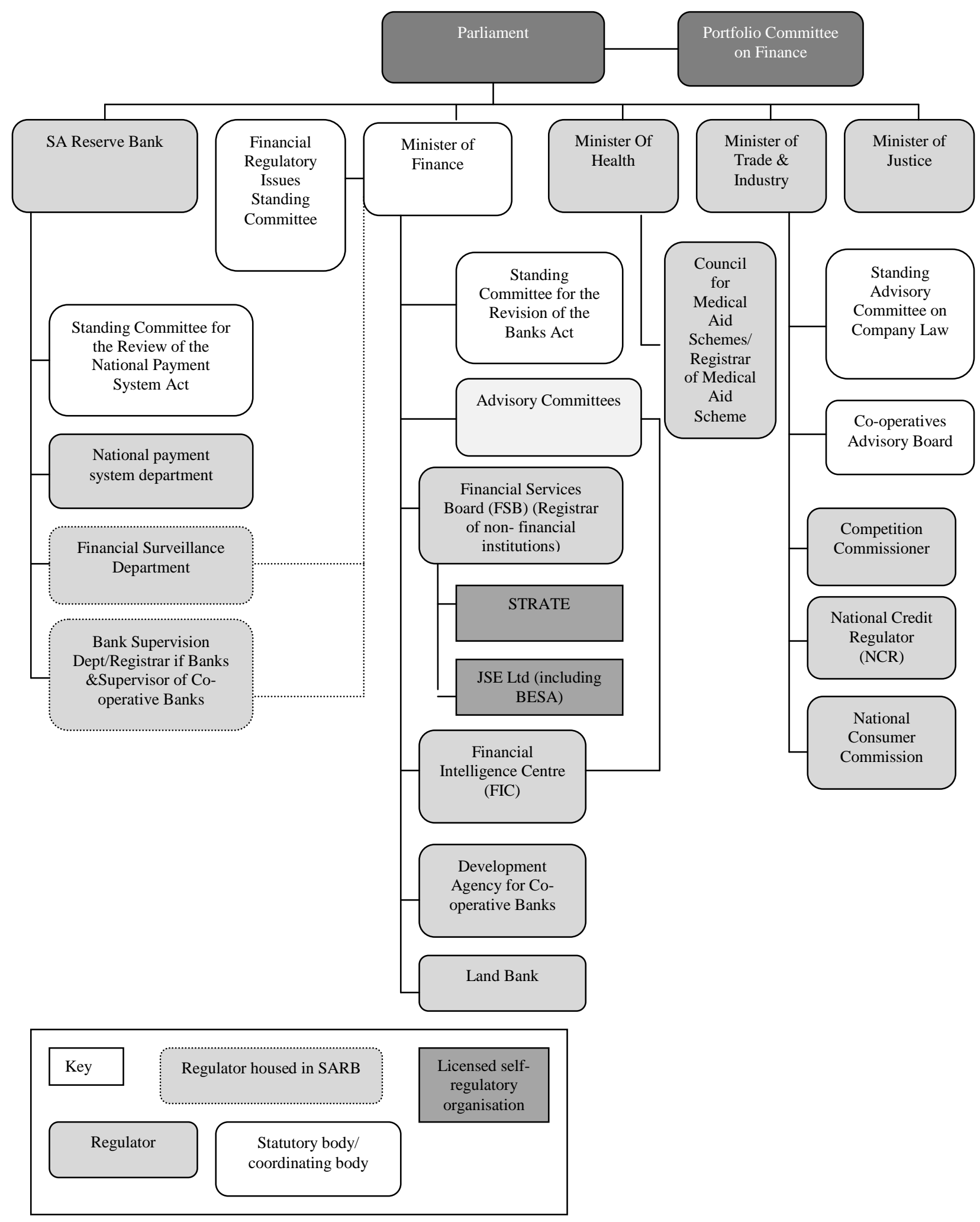
In 2008 the International Monetary Fund (IMF) and the World Bank performed a Financial Sector Assessment Program (FSAP) whereby they conducted a joint assessment of the South African financial system. The main outcome from the IMF team was that although South Africa had a modern and effective financial regulatory framework, it nevertheless needed reform that prioritize and strengthen both prudential and market conduct supervision and regulatory powers (IMF Country Report, 2008). The IMF also observed that due to the implementation of the National Credit Act in 2005, South Africa has made strides in the improvement of consumer protection leading to the decrease in reckless lending practices.

In an effort to address shortcomings in the regulatory structure identified by the IMF, the Government issued the National Treasury Policy Document in February 2011 that set out proposals for strengthening the financial regulatory system. The main policy thrust was the adoption of the twin-peak model of financial regulation in South Africa. It was in part recognition that the country's system of financial regulation was historically linked to the UK and former British colonies, especially Australia and Canada, whose regulatory systems had since been reformed before the global financial crisis. The UK had opted for an integrated system in the 1990s whereby the Financial Services Authority became responsible for regulating all financial services. Australia had adopted the twin-peak model. However, after the global financial crisis there was a global shift away from the integrated (singleregulator) model towards the twin-peak model. South Africa which incidentally was contemplating adopting a single-regulator model from the recommendation of the 1993 Melamet Commission decided to move in line with international trends. Given its current regulatory structure, the adoption of the twin-peaks model was considered to cause the least amount disruption to both market participants and the current regulators. Furthermore, given the country's historical neglect of market conduct regulation, the twin-peaks model was seen as the optimal means of giving sufficient priority to transparency, market integrity and consumer protection. below.

The main elements of South Africa's proposed twin-peak model are diagrammatically shown in Figure 2

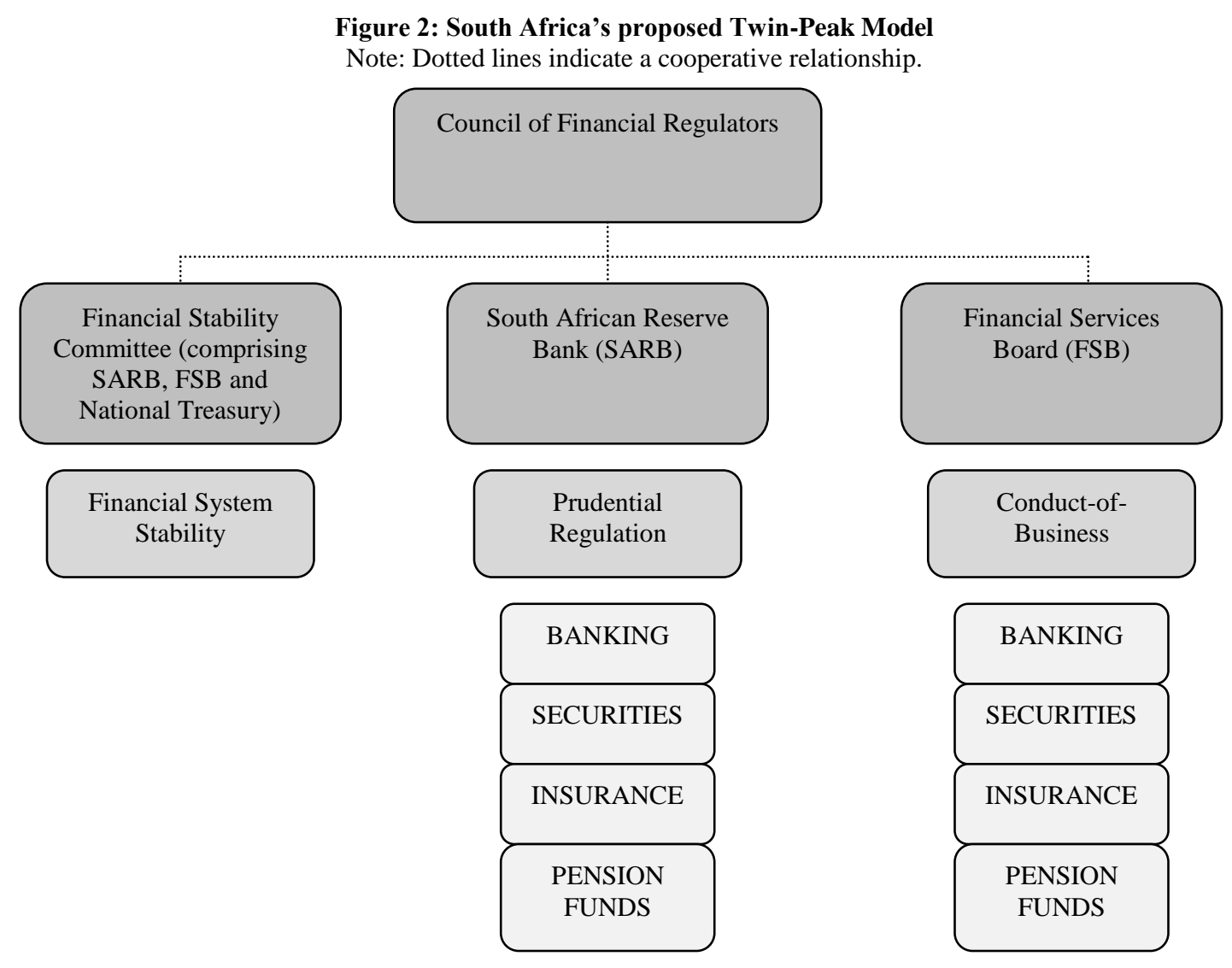


South Africa's twin-peak model will be underpinned by three pillars - coordination, prudential regulation and market conduct of business. The Council of Financial Regulators comprising heads of key financial regulators, non-financial regulators and other stakeholders will ensure overall coordination of financial regulation. It will also serve as a formal channel for resolving conflicts that inevitably arise from separating prudential and market conduct regulation. The Financial Stability Oversight Committee comprising the South African Reserve Bank (SARB), the Financial Services Board (FSB) and National Treasury will coordinate financial stability issues and endeavour to mitigate risks. The South African Reserve Bank (SARB) will be responsible for prudential regulation while the Financial Service Board (FSB) will regulate the conduct of business.

Cognizant of the complexities of the twin-peak approach, South Africa intends to phase in the system over a three year period. It is a realization that the approach requires different skill sets for prudential and market conduct regulation and a transition period would minimize the risk of weakening the capacity of existing regulators.

\section{CONCLUDING REMARKS}

The South African financial regulatory and supervisory system has historically evolved through almost all the stages of the extant regulatory structures. Having started as an institutional approach, it metamorphosed into a functional approach in the late 1980s. In the 1990s the regulatory structure transformed itself into a partially integrated system whose main tenet entailed the central bank regulating the banking sector and a multi-sector regulatory approach for other non-banking financial services. The evolution of the South African regulatory structure has been largely driven by international trends and market imperatives.

While authorities were contemplating adopting the integrated approach which had become fashionable since the 1990s, the global financial crisis struck in 2007 and exposed the weaknesses of the approach. The G30 report (2008) had however indicated that the integrated and twin peak models had been viewed as more efficient and cost-effective not only by regulators but also by the entities. In the aftermath of the global financial crisis, the twinpeak model was viewed to be the most superior model among the alternatives so that advanced countries started in earnest to debate its merits. In line with these international trends, South Africa is in the process of changing its regulatory structure from the partly integrated functional approach to the twin peak regulatory approach. With the twin peak approach South Africa will have a separate regulator for prudential regulation and market conduct regulation. It is hoped the system will increase the coordination and flow of information between the different entities in the financial market and therefore creating better risk management structures which are the main goal of supervision.

\section{AUTHOR INFORMATION}

Dr Makina is Professor of Finance and Banking in the Department of Finance, Risk Management and Banking of the University of South Africa. He has published in recognized national and international journals that include: Applied Financial Economics, Applied Economics, International Business and Economics Research Journal, Journal of Developing Societies, Journal of Accounting and Finance Research, Business Review, African Development Review, African Finance Journal, among others. His research interests are in emerging financial markets, banking and migration issues related to financial development. E-mail: makind@ unisa.ac.za

Miss Botha is a Senior Lecturer in the Department of Finance, Risk Management and Banking of the University of South Africa. Her research interests are in financial regulation, investment and derivative markets. E-mail: bothae2@unisa.ac.za

\section{REFERENCES}

1. $\quad$ Budget Speech, 2011. National Treasury. 23 February 2011.

2. Cecchietti, S. G., 2008. Money, Banking and Financial Markets. $2^{\text {nd }}$ edition. McGraw-Hill Irwin.

3. Cooke, P., 1999. The future of financial regulation. The Financial Regulator, Vol. 4, No. 1, London:

Central Banking Publications, p. 23. 
4. Davies, H. and Green, D., 2008. Global Financial Regulation: The essential guide. MPG Books Ltd, Bodmin, Cornwall.

5. Eichengreen, B. And Bordo, M., 2002. Crises Now and Then: What Lessons from the Last Era of Globalization. National Bureau of Economics Research. Working Paper 8716.

6. Falkena, H; Bamber, R; Llewellyn, D and Store, T., 2001. Financial Regulation in South Africa. $2^{\text {nd }}$ edition. SA financial sector forum.

7. G30 Report, 2008. The structure of financial supervision: Approaches and challenges in a Global Marketplace. Group of Thirty, Washington D.C. 6 October 2008.

8. Goodhart, C., Hartmann, P., Llewellyn, D., Rojas-Suarez and Weisbrod, S., 1998. Financial Regulation: Why, how, and where now? Routledge.

9. IMF, 2009. South Africa Country Report number 08/349 International Monetary Fund, Washington, D.C., 22 October 2009

10. Joskow, P.L. and Noll, R.G., 1981. Regulation in Theory and Practice: An Overview, in Gary Fromm (eds), Studies in Public Regulation (MIT Press, 1981).

11. Masciandaro, D. and Quintyn, M., 2009. Reforming financial supervision and the role of central banks: a review of global trends, causes and effects (1998-2008). Centre for Economic Policy Research, Policy insight No. 30, February 2009.

12. Melamet Commission, 1993. Report of the committee of inquiry into the feasibility of a holistic approach for financial supervision of financial institutions, financial services and deposit-taking institutions. Department of National Treasury, South Africa.

13. Mishkin, F.S., 2004. The Economics of Money, Banking, and Financial Markets. $7^{\text {th }}$ edition. Pearson.

14. National Treasury Policy Document, 2011. A safer financial sector to serve South Africa Better. Department of National Treasury, South Africa, February 2011.

15. Stigler, G.J., 1971. The Theory of Economic Regulation. Bell Journal of Economics and Management Science, Vol. 2, pp.3-21.

16. Taylor, M., 1995. Twin Peaks: A Regulatory Structure for the New Century. London, Centre for the Study of Financial Innovation.

17. Taylor, M. and Fleming, A., 1999. Integrated Financial Supervision: Lessons from Northern European Experience. Policy Research Working Paper No. 223 (Washington: World Bank).

18. The Economist, 2006. Economist Intelligence Unit survey, 2006.

19. Van Zyl, C., Botha, Z., Skerritt, P. And Goodspeed, I. 2009. Understanding South African Financial Markets. Van Schaik Publishers: $3^{\text {rd }}$ Edition.

20. World Bank, 2001. Finance for Growth: Policy Choices in a Volatile World. World Bank Publications. 